\title{
Plasmid Transformation of Azotobacter vinelandii OP
}

\author{
By JAMES L. DORAN, WADE H. BINGLE, KENNETH L. ROY, \\ KOJI HIRATSUKA AND WILLIAM J. PAGE* \\ Department of Microbiology, University of Alberta, Edmonton, Alberta, Canada T6G 2E9
}

(Received 19 December 1986; revised 19 March 1987)

Azotobacter vinelandii OP which had been naturally induced to competence by growth in ironand molybdenum-limited medium was transformed with the broad-host-range cloning vector pKT210. However, the transformation frequency at nearly saturating levels of DNA was 1000fold lower for pKT210 than for a single chromosomal DNA marker (nif ${ }^{+}$). Plasmid- and chromosomal-DNA-mediated transformation events were competitive, magnesium-dependent, $42{ }^{\circ} \mathrm{C}$-sensitive processes specific to double-stranded DNA, suggesting a common mechanism of DNA binding and uptake. The low frequency of plasmid transformation was not related to restriction of transforming DNA or to the growth period allowed for phenotypic expression. Covalently-closed-circular and open-circular forms of pKT210 transformed cells equally well whereas EcoRI- or HindIII-linearized pKT210 transformed cells with two to three times greater efficiency. Genetic transformation was enhanced 10- to 50-fold when pKT210 contained an insert fragment of $\boldsymbol{A}$. vinelandii nif DNA, indicating that $\boldsymbol{A}$. vinelandii possessed a homologyfacilitated transformation system. However, all transformants failed to maintain the plasmidencoded antibiotic resistance determinants, and extrachromosomal plasmid DNA was not recovered from these cells. Flush-ended pKT210 was not active in transformation; however, competent cells were transformed to $\mathrm{Nif}^{+}$by $H$ incll-digested plasmid DNA containing the cloned $A$. vinelandii nif-10 marker.

\section{INTRODUCTION}

The initial studies of plasmid DNA transformation of Azotobacter vinelandii, conducted by David et al. (1981), revealed that cells made artificially competent by a modification of the $\mathrm{CaCl}_{2}$-dependent treatment of Cohen et al. (1972) were transformed by plasmid DNA at frequencies one to three orders of magnitude lower than those observed using chromosomal markers to transform $A$. vinelandii which had been naturally grown to competence (Page, 1985; Page \& von Tigerstrom, 1979). The inherent limitations of plasmid transfer from Escherichia coli to $A$. vinelandii via conjugation (David et al., 1981 ; Kennedy \& Robson, 1983) may mean that transformation of naturally competent $A$. vinelandii is the method of choice for the introduction of plasmids into this organism.

A. vinelandii OP $\left(\right.$ capsule $^{-}$) derivative strains $\mathrm{UW}, \mathrm{UW} 1$ and $\mathrm{UW} 10$ are genetically transformed at high frequencies with single chromosomal markers $\left(10^{-3}-10^{-2}\right.$ transformants per viable cell) when competent cells are prepared naturally, by growth in iron-deficient medium under conditions of oxygen limitation (Page, 1982, 1985; Page \& von Tigerstrom, 1979); this frequency corresponds to $10^{4}-10^{5}$ transformants per $\mu \mathrm{g}$ DNA. Considering the high background of homologous 'non-marker' DNA present in preparations of chromosomal DNA, and the ability of this DNA to compete with and inhibit transformation by 'marker' DNA (Doran \& Page, 1983), it might be expected that nearly all cells in the population attain a competent state.

Abbreviations: CCC, covalently closed circular; OC, open circular. 
This hypothesis predicts that genetic transformation mediated by a single purified DNA species such as a plasmid would be expected to generate $10^{6}-10^{8}$ transformants per $\mu \mathrm{g}$ DNA. The work of Glick et al. (1985) apparently confirmed this supposition by showing that $44 \%$ of cells in a naturally competent population of the encapsulated and poorly transformable (Page, 1985) $A$. vinelandii strain 12837 were transformed by the broad-host-range plasmid pRK2501, although the efficiency of transformation was only $1.5 \times 10^{5}$ transformants per $\mu \mathrm{g}$ DNA. Since studies of $A$. vinelandii physiology, genetics and ultrastructure have most often involved the capsuledeficient strain OP (UW) (e.g. Bingle et al., 1984; Bishop et al., 1985; Brigle et al., 1985; Kennedy \& Robson, 1983; Page \& von Tigerstrom, 1982; Reusch \& Sadoff, 1983), it is important to investigate the nature of plasmid transformation of strain OP (UW) in order to facilitate the development of techniques for the genetic manipulation of this strain.

It has been shown that recombinant plasmids derived from the IncQ plasmid RSF 1010 are useful for gene cloning in $A$. vinelandii $O P$ and are stably maintained when introduced via conjugation (Kennedy \& Robson, 1983) or artificial transformation (David et al., 1981). We have used pKT210 (a derivative of RSF1010) and the cloned $A$. vinelandii nif-10 marker to further characterize the process of natural genetic transformation in $A$. vinelandii OP, and have investigated some ultrastructural features which are strongly correlated with competence for transformation by chromosomal and plasmid DNA. [Some of the results of this study were presented at the 87th Annual Meeting of the American Society for Microbiology, Atlanta, Ga., 6-12 March 1987 (Abstracts of the Annual Meeting of the American Society of Microbiology 1987, H192, p. 171).]

\section{METHODS}

Strains and growth conditions. The capsule - transformation recipient strains, UW (Nif ${ }^{+}$; Bishop \& Brill, 1977), UW1 (nif A Kennedy \& Robson, 1983) and UW10 (nifD; Bishop et al., 1985), were all derivatives of $A$. vinelandii OP. These strains, and the source of rifampicin-resistance (Rif ${ }^{\mathrm{f}}$ ) chromosomal DNA marker, $A$. vinelandii ATCC 12837 strain $113\left(\mathrm{Nif}^{+}\right)$, were routinely grown on Burk medium (Page \& Sadoff, 1976) containing, if necessary, $1.1 \mathrm{~g}$ ammonium acetate $\mathrm{I}^{-1}$. E. coli strains SK1592, HB101 and DH1 (Bolivar \& Backman, 1979; Hanahan, 1983), which served as hosts to plasmid DNA (Table 1$)$, were grown in L-medium $[1 \%(\mathrm{w} / \mathrm{v})$ bactotryptone (Difco), $0.5 \%$ yeast extract (Difco), $0.5 \% \mathrm{NaCl}, 1 \%$ glucose]. $A$. vinelandii strains were incubated in liquid culture at $30^{\circ} \mathrm{C}$ and 170 r.p.m. unless otherwise indicated. Liquid cultures of $E$. coli strains were grown at $37^{\circ} \mathrm{C}$ and 300 r.p.m.

DNA preparation. Crude lysate preparations of chromosomal DNA of $A$. vinelandii strains UW and 113 were obtained as previously described (Page \& Sadoff, 1976). Plasmids were isolated from E. coli SK1592, HB101 or DH1 by standard methods (Maniatis $e$ t al., 1982). Chromosomal DNA concentration was determined by the diphenylamine assay (Hanson \& Phillips, 1981) and plasmid DNA concentration by absorbance at $260 \mathrm{~nm}$. Agarose $(0.75 \%$ ) gel electrophoresis in a $20 \mathrm{~mm}$-Tris/0.2 mM-EDTA/50 mM-sodium acetate, $\mathrm{pH} 7.8$, buffer system and DNA visualization by ethidium bromide staining and UV $(300 \mathrm{~nm})$ illumination were used to confirm that plasmid DNA preparations used in transformation experiments contained almost no visible contaminating RNA or chromosomal DNA and were predominantly composed of the covalently-closed-circular (CCC) form of the plasmid. Small amounts of open-circular $(O C)$ plasmid DNA were typically present in the preparations.

Small-scale preparations of plasmid DNA from $A$. vinelandii were conducted by standard methods (Maniatis $e t$ al., 1982), using cells concentrated 10 -fold from $5 \mathrm{ml}$ of culture; however, it was necessary to develop the following simple and effective procedure for recovering high yields of purified plasmid DNA from $A$. vinelandii. Plasmid DNA was prepared from liquid cultures of $A$. vinelandii $\mathrm{UW}$ grown in medium containing $9 \cdot 2 \mathrm{mM}-\mathrm{K}_{2} \mathrm{HPO}_{4}$, $3.2 \mathrm{mM}-\mathrm{KH}_{2} \mathrm{PO}_{4}, 2 \mathrm{mM}-\mathrm{MgCl}_{2}, 10 \mathrm{mM}-\mathrm{K}_{2} \mathrm{SO}_{4}, 0.5 \mathrm{mM}-\mathrm{CaCl}_{2}, 100 \mu \mathrm{M}-\mathrm{FeSO}_{4}, 30 \mathrm{~mm}$-ammonium acetate and $2 \%$ glucose (the $\mathrm{CaCl}_{2}$ and $\mathrm{FeSO}_{4}$ were added after autoclaving and just prior to inoculation). For the production of large numbers of cells, cultures were grown with vigorous aeration ( $350-400$ r.p.m.) to an optical density at $620 \mathrm{~nm}$ of 6. The cells were harvested by centrifugation $\left(11000 \mathrm{~g}, 10 \mathrm{~min}, 4^{\circ} \mathrm{C}\right)$, washed with 0.04 vols $10 \mathrm{mM}$-Tris/ $\mathrm{HCl}$, $10 \mathrm{~mm}$-EDTA, pH 8.0, and finally resuspended in 0.04 times the original volume of cold $100 \mathrm{~mm}$-Tris $/ 62.5 \mathrm{mM}$ EDTA; $\mathrm{pH}$ 8.0. Lysozyme was added to a final concentration of $500 \mu \mathrm{g} \mathrm{ml}^{-1}$ and the suspension was incubated for 10 min on ice. SDS was added to a final concentration of $2 \%$, and the suspension was mixed immediately by gentle inversion and incubated at room temperature for $20-30 \mathrm{~min}$. A cleared lysate was prepared by centrifugation at $50000 \mathrm{~g}$ for $30 \mathrm{~min}$ at $15^{\circ} \mathrm{C}$ using a Beckman 42.1 rotor in a Beckman model L-8M ultracentrifuge. The nonviscous supernatant was extracted with 1 vol. each of phenol, phenol/chloroform $(1: 1, \mathrm{v} / \mathrm{v})$ and chloroform and the resulting pink supernatant was made $0.3 \mathrm{M}$ with sodium acetate. The DNA was precipitated by the addition of 2.5 
Table 1. Plasmids and E. coli host strains

\begin{tabular}{|c|c|c|c|}
\hline Plasmid & Selectable markers* & E. coli host strain & Reference \\
\hline pKT210 & $\mathrm{Cm}^{r} \mathrm{Sm}^{r}$ & SK 1592 & Bagdasarian et al. (1981) \\
\hline pSa747 & $\mathrm{Km}^{\mathrm{r}} \mathrm{Sp}^{\mathrm{r}}$ & $\mathrm{HB101}\left(\mathrm{Sm}^{r}\right)$ & Tait et al. (1983) \\
\hline pSa30 & nifHDK & HB101 & Cannon et al. (1979) \\
\hline pUC8 & $\mathrm{Ap}^{\mathrm{r}}$ & JM83 & Vieira \& Messing (1982) \\
\hline pAvH1 & $\mathrm{Km}^{r} \mathrm{Sp}^{r}$ & HBI0I & This study \\
\hline pAvH1-1 & $\mathrm{Ap}^{\mathrm{r}}$ nif $\mathrm{D}-10 \dagger$ & HBiol & This study \\
\hline pAvD-10 & $\mathrm{Cm}^{r} \mathrm{Sm}^{\mathrm{r}}$ nifD-10 & $\mathrm{DH} 1\left(\mathrm{Sm}^{\mathrm{s}}\right)$ & This study \\
\hline
\end{tabular}

* Apr, ampicillin resistance; $\mathrm{Cm}^{r}$, chloramphenicol resistance; $\mathrm{Km}^{r}$, kanamycin resistance; $\mathrm{Sm}^{r}$, streptomycin resistance; $\mathbf{S m}^{\text {s }}$, streptomycin sensitivity; $\mathbf{S p}^{r}$, spectinomycin resistance.

$\dagger$ nifD-10 represents a cloned region of wild-type $A$. vinelandii DNA corresponding to the nif- $10(n i f D)$ mutation of strain UW10 (Bishop \& Brill, 1977; Bishop et al., 1985).

vols $95 \%(\mathrm{v} / \mathrm{v})$ ethanol, collected by centrifugation $\left(4000 \mathrm{~g}, 30 \mathrm{~min}, 4^{\circ} \mathrm{C}\right)$ and dried under vacuum until the pellet appeared slightly moist. The pellet was resuspended in TE buffer $(10 \mathrm{~mm}-\mathrm{Tris} / \mathrm{HCl}, 1 \mathrm{mM}-\mathrm{EDTA}, \mathrm{pH} 8.0)$ with $\mathrm{CsCl}\left(1.1 \mathrm{~g} \mathrm{ml}^{-1}\right)$ and ethidium bromide $\left(250 \mu \mathrm{g} \mathrm{ml}^{-1}\right)$. The gradients were centrifuged in a Beckman $50 \mathrm{Ti}$ rotor $\left(100000 \mathrm{~g}, 40 \mathrm{~h}, 20^{\circ} \mathrm{C}\right)$ and the plasmid DNA band was recovered and purified by another round of $\mathrm{CsCl} /$ ethidium bromide density gradient centrifugation (Maniatis et al., 1982). This protocol typically yielded $0.5-$ $1 \mathrm{mg}$ pKT210 DNA from 21 A. vinelandii UW culture.

Transformation. Competent $A$. vinelandii UW, UWl or UW10 cells were prepared and transformed as previously described (Doran \& Page, 1983; Page, 1985) with the modifications that the transformation assay buffer included ammonium acetate $\left(1 \cdot 1 \mathrm{~g}^{-1}\right)$ and $1 \%$ glucose when cells were transformed to antibiotic resistance and $\mathrm{MoO}_{4}^{2-}$ was excluded from all transformation assays. $\mathrm{Nif}^{+}$transformants were selected by plating cells on nitrogen-free Burk medium. Cells transformed to antibiotic resistance were plated directly on selective medium or were incubated for $3 \mathrm{~h}$ in liquid culture under non-selective conditions prior to plating. In the latter case, $100 \mu \mathrm{l}$ iron-limited Burk medium, $50 \mu 15 \%$ yeast extract and $2.5 \mu 120 \mathrm{mM}-\mathrm{FeSO}_{4}$ were added to the transformation assay $(350 \mu \mathrm{l}$ total volume) prior to incubation. All transformation experiments were done at least twice and the mean transformation frequencies, expressed as the number of transformants per viable cell, are reported.

E. coli $\mathrm{HB} 101$ cells were made competent and transformed with plasmid DNA as described by Morrison (1979). CompetCompetent $E$. coli $\mathrm{DH} l$ cells were prepared and transformed according to the method of Hanahan (1983).

Electron microscopy. Freeze-etch replicas of cells were prepared as described previously (Bingle et al., 1984). Ultrathin sections of plasmolysed cells were prepared by a modification of the method of Bayer \& Thurow (1977). All specimens were examined in a Philips 300 electron microscope operated at an accelerating voltage of $80 \mathrm{kV}$.

\section{RESULTS AND DISCUSSION}

\section{Transformation of A. vinelandii with $p K T 210$}

pKT210, a plasmid cloning vector developed from the broad-host-range plasmid RSF1010 (Bagdasarian et al., 1981; Fig. 1), was chosen for this study since plasmids of the IncQ group have been found to replicate in $A$. vinelandii strain UW (David et al., 1981). Additionally, expression of the chloramphenicol resistance marker of pKT210 was conveniently selected for by differences in the growth rates of transformed and non-transformed cells without a period of growth under nonselective conditions, a feature arising from the relatively high level of inherent chloramphenicol resistance of $\boldsymbol{A}$. vinelandii OP and related strains (Thompson \& Skerman, 1979). Detection of chloramphenicol-resistant $\left(\mathrm{Cm}^{\mathrm{r}}\right)$ pKT210 transformants was optimal when Burk medium contained $0.5 \%$ yeast extract, as the source of fixed nitrogen (David et al., 1981), and $20 \mu \mathrm{g}$ chloramphenicol ml-1. Transformation assays done with $10 \mu \mathrm{g}$ pKT210 DNA and approximately $1 \times 10^{7}$ cells from a competent population of $A$. vinelandii UW10 routinely yielded $0.5-1 \times 10^{-4} \mathrm{Cm}^{r}$ or streptomycin-resistant $\left(\mathrm{Sm}^{r}\right)$ transformants per viable cell. All $\mathrm{Cm}^{r}$ transformants were viable on Burk medium containing $0.2 \mu \mathrm{g}$ streptomycin $\mathrm{ml}^{-1}$ (twice the concentration required to completely inhibit the growth of nontransformed cells) and vice versa. Plasmid DNA prepared from representative transformants comigrated on agarose gels with pKT210 purified from $E$. coli (data not shown). 


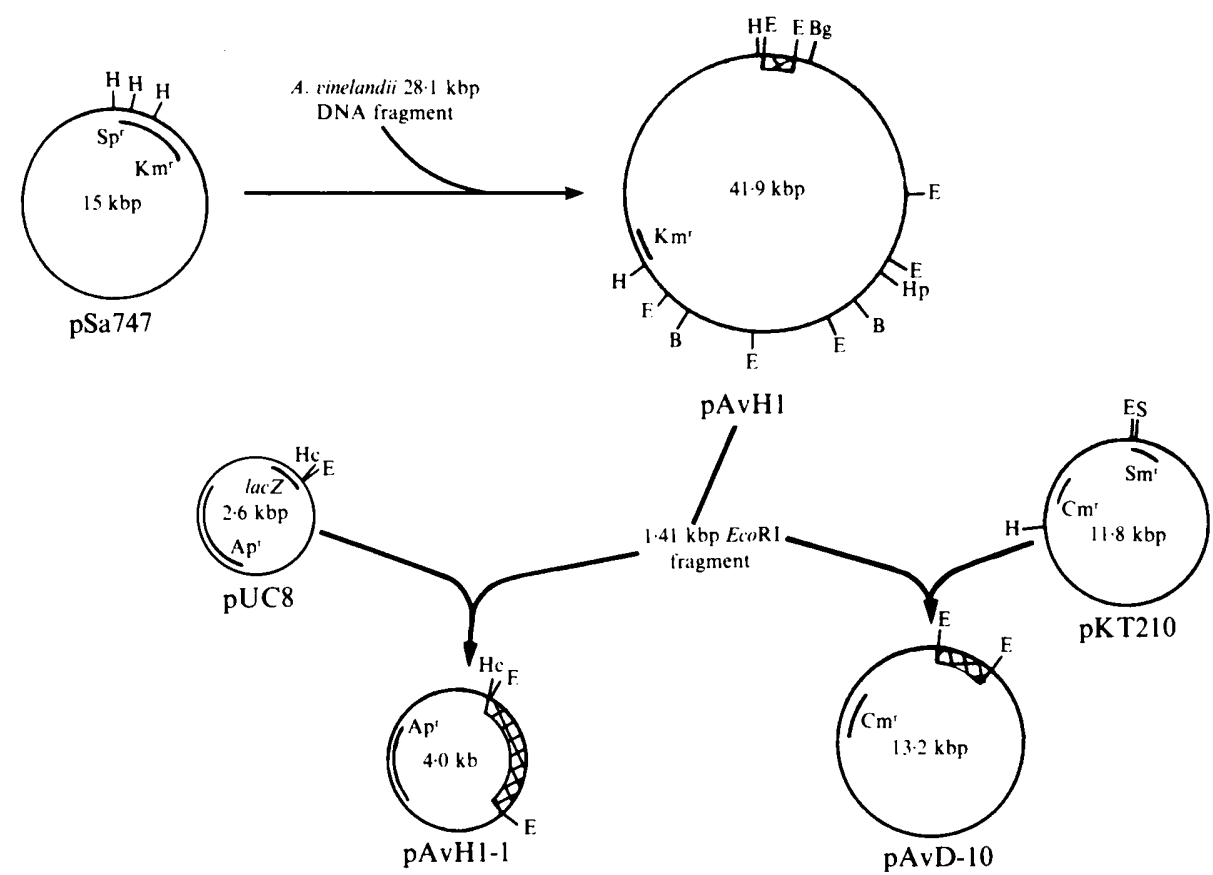

Fig. 1. Schematic representation of the construction of pAvD-10 (not drawn to scale). The cosmid pAvH 1 was selected from a library of size-fractionated HindIII-digested $A$. vinelandii strain UW DNA constructed in the cosmid pSa747 (Collins, 1979; Hohn, 1979). A 1.41 bp EcoRI A. vinelandii DNA fragment present in pAvHl-1 was determined by hybridization to pSa30 to contain homology to $K$. pneumoniae nifHDK (cross-hatched area) and was subcloned into pUC8 for detailed restriction mapping and nucleotide sequence analysis (see Fig. 3). This fragment was also subcloned into the broad-host range vector $\mathrm{pKT} 210$ to form the plasmid $\mathrm{pAvD}-10$ for use in plasmid transformation studies. Restriction enzyme sites are abbreviated as: $\mathrm{Bg}, \mathrm{Bg} / \mathrm{II}$; B, BamHI; E, EcoRI; H, HindIII; Hc, HincII; Hp, HpaI; P, PvuII. Other abbreviations are explained in the legend to Table 1.

The transformation frequency of UW10 by pKT210 represented approximately one transformant per $10^{9}$ plasmid molecules and was about 1000 -fold lower than the average Nif ${ }^{+}$ transformation frequency obtained when UW 10 was transformed with $10 \mu \mathrm{g}$ crude lysate UW chromosomal DNA $\left(4-7 \times 10^{-2}\right.$ transformants per viable cell), a heterogeneous mixture of homologous chromosomal DNA markers. pKT210 was similarly inefficient in transforming competent strains UW or UWl prepared naturally by growth in iron- and molybdenum-limited medium (data not shown).

The lack of an initial growth period under nonselective conditions was not responsible for the poor levels of pKT210-mediated transformation. The $\mathrm{Cm}^{\mathrm{r}}$ or $\mathrm{Sm}^{\mathrm{r}}$ transformation frequency obtained after $3 \mathrm{~h}$ growth of newly-transformed cells in Burk medium $\left(6.8 \times 10^{-5}\right)$ was equivalent to that obtained when cells were plated directly on selective medium $\left(6.5 \times 10^{-5}\right)$. However, when the concentration of antibiotics in the selective medium was doubled $(40 \mu \mathrm{g}$ chloramphenicol ml $\mathrm{m}^{-1}$ or $0.4 \mu \mathrm{g}$ streptomycin $\mathrm{ml}^{-1}$ ), a $3 \mathrm{~h}$ incubation period under nonselective conditions was required to avoid a twofold reduction in transformation frequency to $3.5 \times 10^{-5}$. Consistent with these results, pKT210 was found to be maintained in strain UW10 in the absence of antibiotic selection pressure for at least six generations, since such cultures contained comparable numbers of $\mathrm{Cm}^{\mathrm{r}}\left(5.5 \times 10^{7}\right)$ and $\mathrm{Sm}^{\mathrm{r}}\left(5.9 \times 10^{7}\right)$ and total viable $\left(5.1 \times 10^{7}\right)$ cells $\mathrm{ml}^{-1}$.

The low transformation frequency was not attributable to restriction of pK T210 prepared from $E$. coli since $10 \mu \mathrm{g}$ pK T210 purified from $A$. vinelandii $\mathrm{UW}$ or $E$. coli SK 1592 transformed about $1 \times 10^{7}$ cells from a common population of competent $A$. vinelandii $\mathrm{UW} 10$ at frequencies of $6.2 \times 10^{-5}$ and $6.1 \times 10^{-5}$, respectively. 


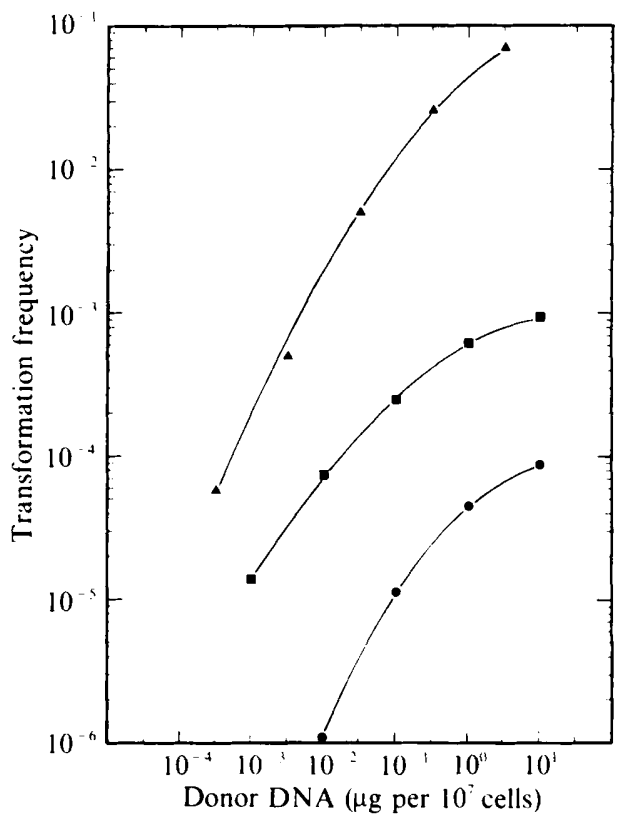

Fig. 2. Effect of plasmid and chromosomal DNA concentration on transformation of competent strain UW 10. Transformation assays were done as described in Methods. Strain UW10 was transformed to $\mathrm{Cm}^{r}$ and $\mathrm{Sm}^{r}$ by pKT210 (O) or to $\mathrm{Nif}^{+}$by pAvD-10 ( $\mathrm{G}$ ) or strain UW chromosomal DNA (A). Transformation frequency is expressed as the number of transformants per viable cell.

Transformation with pKT210 was measured using nearly saturating concentrations of plasmid DNA (Fig. 2). In a transformation assay with $1 \times 10^{7}$ cells of strain UW10, a tenfold increase in pK T210 DNA from $10 \mathrm{ng}$ to $100 \mathrm{ng}$ resulted in a tenfold increase in transformation frequency (Fig. 2). However, at levels of pKT210 DNA greater than $100 \mathrm{ng}$, the number of transformants per $\mu \mathrm{g}$ DNA decreased rapidly and $10 \mu \mathrm{g}$ pK T210 approached saturating levels of DNA. Although the frequencies of transformation observed with pK T210 were consistently 1000-fold lower than those observed with an equivalent amount of homologous chromosomal DNA, the levels of DNA at which saturation became evident were approximately the same (Fig. 2). Therefore, both pKT210 DNA and homologous chromosomal DNA were capable of saturation of an early stage in transformation although pK T210 DNA apparently participated very inefficiently at some later stage(s) in the process.

Since the topology of plasmid DNA has been observed to affect transforming activity in other naturally competent bacteria, including Streptococcus pneumoniae (Saunders \& Guild, 1981), Streptococcus sanguis (Behnke, 1981), Bacillus subtilis (de Vos et al., 1981) and Haemophilus influenzae (Gromkova \& Goodgal, 1981; Kahn et al., 1983), it was of interest to determine whether the activity of pK T210 in A. vinelandii transformation was independent of its steric conformation. As indicated in Table 2, the CCC and OC forms of pKT210 transformed cells of strain UW 10 equally well. However, linear duplex plasmid DNA which had been generated by digestion with EcoRI or HindIII to produce cohesive termini transformed cells to $\mathrm{Cm}^{\mathrm{r}}$ and $\mathrm{Sm}^{\mathrm{r}}$ with two- to threefold greater efficiency than circular plasmid DNA (Table 2). Similar results were obtained in experiments using strain UW1 (data not shown). Plasmid DNA isolated from cells transformed with HindIII- or EcoRI-linearized pK T210 comigrated on agarose gels with pKT210 DNA purified from $E$. coli (data not shown). Oligomeric plasmid molecules were never isolated from transformed cells. These data suggest that an efficient mechanism for recircularization or ligation exists in $A$. vinelandii. Plasmid DNA recovered from cells transformed with linear plasmids was digested with the restriction enzyme used to linearize the original transforming DNA molecule; therefore the recircularization process did not involve deletion of the $5^{\prime}$ or $3^{\prime}$ terminal sequences. 


\section{Table 2. Effect of pKT210 topology on genetic transformation}

\begin{tabular}{|c|c|c|c|c|c|c|}
\hline \multirow{3}{*}{$\begin{array}{l}\text { Selectable } \\
\text { marker }\end{array}$} & \multicolumn{6}{|c|}{$10^{4} \times$ No. of transformants per cell ${ }^{*}$} \\
\hline & \multicolumn{6}{|c|}{$\begin{array}{l}\text { Plasmid conformation: } \\
\text { Linearized }\end{array}$} \\
\hline & $\mathrm{CCC}$ & $\mathrm{OC}^{\dagger}$ & HindIII & EcoRI & Flush-ended & Denatured $\S$ \\
\hline $\begin{array}{l}\mathrm{Cm}^{r} \\
\mathrm{Sm}^{r}\end{array}$ & $\begin{array}{l}1.0 \\
1.2\end{array}$ & $\begin{array}{l}1.4 \\
1.2\end{array}$ & $\begin{array}{l}3 \cdot 7 \\
3 \cdot 6\end{array}$ & $\begin{array}{l}3 \cdot 6 \\
4 \cdot 2\end{array}$ & ND & $\begin{array}{l}\text { ND } \\
\text { ND }\end{array}$ \\
\hline
\end{tabular}

ND, No transformants were detected; therefore, the transformation frequency was less than $1 \times 10^{-7}$.

* Strain UW10 was transformed with $10 \mu \mathrm{g}$ plasmid DNA as described in Methods.

+ CCC pKT210 was converted to the OC form by treatment with topoisomerase 1 as recommended by the supplier (Pharmacia).

$\ddagger$ Flush-ended linear DNA was generated from HindIII-linearized pK T210 using the Klenow fragment of DNA polymerase I as described by Maniatis et al. (1982). The success of this 'fill-in' reaction was monitored in a parallel reaction in which $\left[\alpha^{-32}\right.$ P]dATP was included as a radioactive tracer.

$\S$ HindIII-linearized DNA was denatured by heating at $100^{\circ} \mathrm{C}$ for $6 \mathrm{~min}$ in TE buffer and immediately immersing the sample in an ice bath.

It was possible that perfect recircularization of the linear transforming DNA was solely facilitated by the single-stranded, self-annealing termini generated by EcoRI or HindIII digestion. To determine whether this was true, the single-stranded ends of HindIII-digested pKT210 were made double-stranded using the Klenow fragment of DNA polymerase I and unlabelled deoxynucleoside triphosphates (Maniatis et al., 1982). The linear, flush-ended form of pKT210 failed to generate any $\mathrm{Cm}^{r}$ or $\mathrm{Sm}^{r}$ transformants from a competent population of strain UW1 (CCC pKT210 $\mathrm{Sm}^{\mathrm{r}}$ transformation frequency $4 \times 10^{-5}$ ). Therefore, the transformation frequency obtained using a preparation of predominantly CCC pK T210 may have been slightly reduced due to competition by nontransforming randomly sheared plasmid DNA; however, this would not account for the difference in transformation efficiency between circular and HindIII- or EcoRI-linearized plasmid DNA since each of these preparations was approximately equivalently contaminated (on a per $\mu \mathrm{g}$ basis) by linear DNA that did not possess cohesive ends.

\section{Homology-facilitated plasmid transformation}

The low frequency of pK T210 transformation may have been due to the heterologous nature of this plasmid since transformation mediated by chromosomal DNA markers was found to discriminate against heterologous DNA (Doran \& Page, 1983). In order to determine whether the phenomenon of homology-facilitated transformation was responsible for the discrimination against transformation by pKT210, a derivative of pKT210 containing an insert fragment of wild-type nif DNA from strain UW was obtained. By virtue of hybridization (Gergens et al., 1979 ) to the $K$. pneumoniae nifHDK insert of pSa30, a clone containing $A$. vinelandii nif DNA was selected from a library of $A$. vinelandii UW DNA formed in the cosmid pSa747 (Fig. 1). Physical mapping (Fig. 1) and Southern (1979) hybridization analysis (not shown) of this recombinant, designated $\mathrm{pAvH1}$, identified a $1.4 \mathrm{kbp}$ hybridizing EcoRI fragment. This fragment was subcloned into pUC8, to form the plasmid designated pAvH1-1 (Fig. 1), for the determination of a detailed restriction map (Fig. 3). Subclones prepared in M13 mp8 and M13 mp9 (Fig. 3) permitted DNA sequence analysis by the dideoxy primer extension method (Sanger et al., 1977). The $1.41 \mathrm{kbp} E c o$ RI fragment was found to encode a region of the $A$. vinelandii nifHDK gene cluster previously sequenced by Brigle et al. (1985) (therefore the data are not shown). A single difference between the DNA sequence obtained and that reported by Brigle et al. (1985) was that the nucleotide at position 7 of the nif $D$ gene was determined to possess a guanine rather than a cytosine residue, a difference which was reflected in the presence of an $M s p I$ site at this position (Fig. 3). By virtue of this difference our sequence indicated that the third amino acid encoded by the nifD gene was a glycine residue, a prediction consistent with the protein sequence of the $\alpha$-subunit of $A$. vinelandii nitrogenase reported by Lundell \& Howard (1981). 


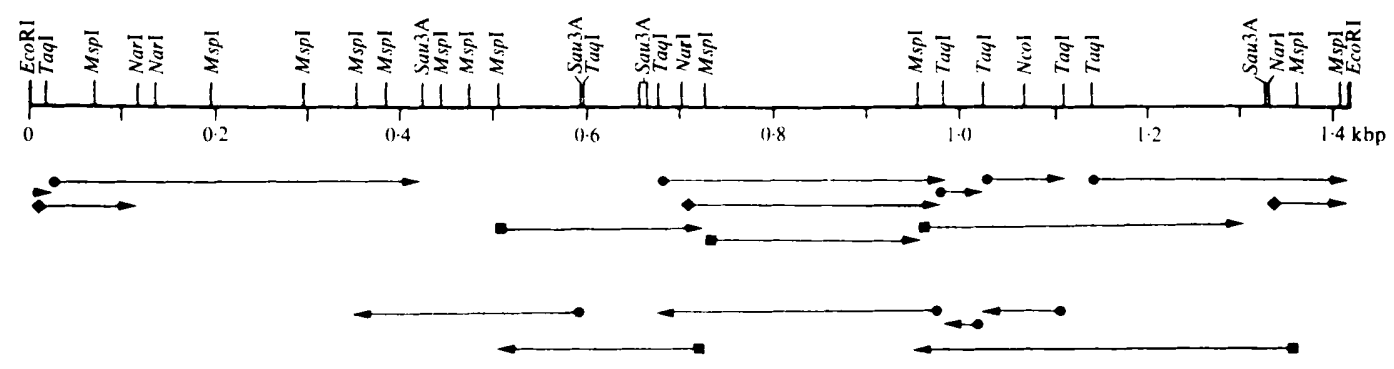

nif $D$

Fig. 3. Restriction map and DNA sequencing strategy of the insert DNA of the plasmid subclone pAvH 1-1. The arrows indicate sequencing gel readings initiating from $M s p \mathrm{I}(\square), T a q \mathrm{I}(\bigcirc)$ or other $(\bullet)$ sites. One EcoRI site, located 350 bp $3^{\prime}$ to the terminal HindIII site indicated in Fig. 1, was situated within the nifH gene, 189 bp $5^{\prime}$ to the nifD gene and the second $E c o$ RI site was situated within the nifD coding region 249 bp from the $3^{\prime}$ end.

This $1.41 \mathrm{kbp}$ EcoRI fragment was predicted, on the basis of the results of Bishop et al. (1985), and confirmed, on the basis of pAvH1-1-mediated transformation of UW10 to $\mathrm{Nif}^{+}$(data not shown), to contain the wild-type locus corresponding to the nif-10 mutation of UW 10 (Bishop \& Brill, 1977). Since Robinson et al. (1986) had discovered that plasmids containing $A$. vinelandii DNA were not maintained as independently replicating elements in $A$. vinelandii but rather integrated into the chromosome, it was not considered important to have cloned the complete nifHDK operon in order to allow complementation of nif- 10 mutation in trans. The $1.41 \mathrm{kbp}$ EcoRI fragment containing the wild-type nif- 10 locus was cloned into the EcoRI site of pKT210 to produce a plasmid, designated $\mathrm{pAvD}-10$, which was suitable for use in these transformation studies (Fig. 1).

Over a range of plasmid DNA concentrations from $1 \mathrm{ng}$ to $10 \mu \mathrm{g}$ per $10^{7}$ cells, the nif- 10 marker of pAvD-10 (13.2 kbp) consistently demonstrated 10-100 times greater activity in the transformation of strain UW 10 than did the $\mathrm{Cm}^{\mathrm{r}}$ or Sm $\mathrm{Sm}^{\mathrm{r}}$ markers of pK T210 (11.8 kbp) (Fig. 2). Since no vector sequences were deleted from $\mathrm{pKT} 210$ during the construction of $\mathrm{pAvD}-10$, this effect can be attributed to the presence of the homologous chromosomal DNA insert. No Nif ${ }^{+}$ pAvD-10-transformed UW10 were $\mathrm{Cm}^{\mathrm{r}}$ or $\mathrm{Sm}^{\mathrm{r}}$ and no plasmid DNA was recovered from pAvD-10-transformed cells. Moreover, no $\mathrm{Cm}^{r} \mathrm{Nif}^{-}$of $\mathrm{Sm}^{\mathrm{r}} \mathrm{Nif}^{-}$transformants were detected by direct selection on media containing antibiotic and a source of fixed nitrogen. Therefore, the presence of a homologous DNA insert did not facilitate the transformation by plasmids per se. As illustrated by the curves in Fig. 2, transformation mediated by either pAvD-10 or pKT210 became saturated at levels of DNA greater than $1 \mu \mathrm{g}$ per $10^{7}$ cells. This implied that the greater frequency of transformation by pAvD-10 was the result of enhanced uptake or survival of the plasmid-encoded nif-10 marker. Since selection of the nif-10 marker involves a selection for recombination the data do not distinguish between these two possibilities.

Notably, pAvD-10 transformed cells 10- to 100-fold less effectively than homologous chromosomal DNA prepared from strain UW (Fig. 2). Therefore, the absence of homologous DNA sequences in pKT210 only partially accounted for the poor levels of transformation by this plasmid. Interestingly, HindIII linearization of $\mathrm{pAvD}-10$ increased the $\mathrm{Nif}^{+} \mathrm{pAvD}-10$ transformation frequency of strain UW10 $\left(1-2 \times 10^{-3}\right)$ twofold $\left(2-4 \times 10^{-3}\right)$, thereby demonstrating that this linearization of plasmid DNA promoted transformation regardless of whether the transforming DNA became integrated into the chromosome or was maintained as an extrachromosomal element. Cells of strain UW 10 which were competent for transformation to $\mathrm{Nif}^{+}$by chromosomal DNA $\left(2 \times 10^{\circ}\right)$ were transformed to $\mathrm{Nif}^{+}$by $\mathrm{pAvH1-1}$ digested with HinclI (which cut only once within the plasmid: Fig. 1) at a frequency of $7 \cdot 1 \times 10^{-4}$, which was approximately half the $\mathrm{Nif}^{+}$transformation frequency obtained using HindIII-digested 
pAvH1-1 (1.2 $\left.\times 10^{-3}\right)$. Therefore, flush-ended plasmid DNA containing a homologous DNA insert was not excluded from uptake into competent cells.

\section{Requirements for plasmid transformation}

Since the results presented above suggested that plasmid and chromosomal transformation may occur by the same mechanism, it was of interest to determine whether the physiological state of competence for plasmid transformation was the same as that for homologous chromosomal DNA transformation.

Similar to the development of competence for transformation by chromosomal DNA, the induction of competence in $A$. vinelandii strains UW, UW1 or UW10 for transformation by pKT210 required a period of growth under oxygen- and iron-limited conditions (Page, 1982, 1985; Page \& von Tigerstrom, 1978), since no $\mathrm{Cm}^{r}$ or $\mathrm{Sm}^{r}$ transformants of strain UW 10 grown under conditions of iron-limitation and high aeration, or in iron-containing Burk medium, were detected.

The process of genetic transformation of $A$. vinelandii by chromosomal DNA was shown by Doran \& Page (1983) to be a $42{ }^{\circ} \mathrm{C}$-sensitive, $\mathrm{Mg}^{2+}$-dependent event specific for duplex DNA. In that study, several probing experiments suggested that the loss of competence that occurred on heating cells at $42^{\circ} \mathrm{C}$ was either the result of a loss of the ability of cells to transport the transforming chromosomal DNA across the cell envelope or was the result of a failure of donor DNA to bind to the correct cell surface receptor. Similarly, no $\mathrm{Cm}^{r} \mathrm{Sm}^{\mathrm{r}}$ or Nif ${ }^{+} \mathrm{UWl}$ transformants were produced when competent UWl cells were treated at $42{ }^{\circ} \mathrm{C}$ for $30 \mathrm{~min}$ before exposure to $10 \mu \mathrm{g}$ pKT210, pAvH1-1 or UW chromosomal DNA, although unheated cells were transformed at typical frequencies. Also, no $\mathrm{Cm}^{\mathrm{r}}$ or $\mathrm{Sm}^{\mathrm{r}}$ transformants of unheated competent strain UWl were detected when the cells had been washed once in iron- and molybdenum-limited Burk medium lacking magnesium and then exposed to $10 \mu \mathrm{g}$ pKT210 DNA in transformation assay buffer lacking magnesium. $\left[\mathrm{Mg}^{2+}\right.$ has been shown to be required for DNAase-resistant DNA binding to competent strain UW1 (Doran \& Page, 1983).] Moreover, single-stranded plasmid DNA was not active in transformation since heat-denatured $\left(100{ }^{\circ} \mathrm{C}, 6 \mathrm{~min}\right)$, Hind III-linearized $\mathrm{pKT} 210$ failed to generate any $\mathrm{Cm}^{\mathrm{r}}$ or $\mathrm{Sm}^{\mathrm{r}}$ transformants of competent strain UW1 (Table 2).

These results suggested that transformation by plasmid DNA shared the same mechanism of DNA binding and uptake as transformation by chromosomal DNA. If this were true, then exposure of competent cells to plasmid DNA should inhibit transformation by chromosomal DNA since transformation was a saturable process (Fig. 2). In order to measure the ability of plasmid DNA to inhibit transformation by chromosomal DNA of strain $113,1 \cdot 1 \times 10^{7}$ cells from a competent population of strain UW1 ( Rif $^{r}$ transformation frequency $9.5 \times 10^{-3}$ ) were exposed to $5 \mu \mathrm{g}$ pKT210, pAvD-10 or UW chromosomal DNA for $20 \mathrm{~min}$ at $30^{\circ} \mathrm{C}$ prior to exposure to $5 \mu \mathrm{g}$ strain $113 \mathrm{DNA}\left(\mathrm{Nif}^{+} \mathrm{Rif} \mathrm{r}^{\mathrm{r}}\right.$ ). Exposure of cells to pKT210, pAvD-10 and UW DNA reduced transformation to Rif $^{r}$ by $66 \%\left(3.2 \times 10^{-3}\right), 72 \%\left(2 \cdot 7 \times 10^{-3}\right)$ and $83 \%$ $\left(1.6 \times 10^{-3}\right)$, respectively. Previous studies using chromosomal DNA have demonstrated a similar rough correlation between the ability of a DNA species to inhibit transformation by a second DNA species and the biological activity of the first DNA species in genetic transformation (Doran \& Page, 1983). However, it is important to note that the competitive abilities of the DNA species used in this study were almost equivalent by comparison to their very disparate transforming activities; therefore, at least one of the steps in transformation at which these DNA species were competing did not discriminate against heterologous plasmid DNA as much as some later step. Previous work had shown that exposure of $42^{\circ} \mathrm{C}$-treated cells to excess homologous DNA prevented further transformation of the cells following a period of incubation at $30^{\circ} \mathrm{C}$ which otherwise would have resulted in a recovery of competence, thereby indicating that competition between transforming DNA species probably occurred at the stage of DNA binding in the cell envelope (Doran \& Page, 1983). Therefore, there appeared to be common events in the process of binding and uptake of plasmid and chromosomal DNA and at least one of these events was biased in favour of homologous DNA sequences. 


\section{Competence-specific ultrastructural features of $\boldsymbol{A}$. vinelandii}

Competent cells of $H$. influenzae possess anatomical features referred to as 'transformasomes'; these are membranous extensions from the cell surface, clearly visible by analysis of thin sections, on which the components of the homology-facilitated (Danner et al., 1980), heatsensitive (Deich \& Hoyer, 1982) DNA binding and uptake system are localized (Barany et al., 1983; Kahn et al., 1982, 1983; Pifer \& Smith, 1985). Homology-facilitated transformation of $A$. vinelandii does not appear to involve analogous structures because examination of ultrathin sections of competent $A$. vinelandii has not revealed any similar features or any other competence-specific features (data not shown).

Freeze-etch electron microscopy, however, has revealed a competence-specific feature related to the cell envelope. Approximately $25 \%$ of the cells in a competent population of strain UW 1 ( $\mathrm{Nif}^{+}$transformation frequency $1.6 \times 10^{-2}$ ) which exhibited cleavage planes through the inner membrane were often interrupted by three to nine 'patches' of outer membrane material on which the outer membrane fracture face was exposed (Fig. $4 a$ ). An accurate number of 'patches' per cell could not be estimated, as often a fracture plane which had switched to the hydrophobic region of the outer membrane failed to return immediately to the inner membrane fracture plane, possibly preventing more 'patches' from being revealed. These 'patches' were apparent in UW1 after $13 \mathrm{~h}$ incubation in iron-limited, competence-induction medium just prior to the appearance of competence (data not shown; Page \& von Tigerstrom, 1978) and they continued to be present in cells following $36 \mathrm{~h}$ incubation in competence induction medium although competence had declined ( $\mathrm{Nif}^{+}$transformation frequency $1.3 \times 10^{-6}$ ). The basis for this decline is not understood; however it may be related to the effects of prolonged $\mathrm{O}_{2}$-starvation (Page, 1982) rather than a loss of competence-related function.

Cells from a competent population of strain UW1 which had apparently lost the ability to transport or appropriately bind transforming DNA following treatment at $42{ }^{\circ} \mathrm{C}$ (Doran \& Page, 1983) did not possess these 'patches' demonstrable by freeze-etch techniques. Significantly, these structures were visualized on cells from the $42{ }^{\circ} \mathrm{C}$-treated population following incubation at $30^{\circ} \mathrm{C}$ and competence redevelopment ( $\mathrm{Nif}^{+}$transformation frequency $1.5 \times 10^{-2}$; data not shown). Moreover, freeze-etch preparations of non-competent strain UW1 prepared by growth in iron-sufficient Burk medium or in iron-limited Burk medium containing glutamate as the sole source of nitrogen (Page \& von Tigerstrom, 1978) or in iron-limited medium under conditions of high aeration (Page, 1982) did not possess these 'patches' (data not shown). Therefore, these 'patches' were considered to be indicative of competence-specific alterations in the cell envelope which were very tentatively correlated with the ability of cells to take up transforming DNA.

Anatomical features similar to these 'patches' have been observed in $E$. coli and were considered to represent either sites of adhesion between the inner and outer membranes (Bayer \& Lieve, 1977) or discrete regions of phospholipid coalescence (Ferris \& Beveridge, 1986). Since membrane adhesion sites have been implicated as the sites at which several bacteriophage inject DNA into $E$. coli (Bayer, 1979) and have also been observed adjacent to the transformasomes of competent $H$. influenzae (Kahn et al., 1982) this possibility was considered worthy of investigation. Ultrathin sections of cells were obtained from populations of competent and $42{ }^{\circ} \mathrm{C}$-treated formerly-competent $A$. vinelandii revealed an average of 1.5 adhesion sites in the plane of thin sections of randomly oriented, completely plasmolysed cells (see Fig. $4 b$ ). Given that the average thickness of these silver-grey sections was approximately $60-80 \mathrm{~nm}$ (Peachy, 1958) and that the cells had an average diameter of $1.5 \mu \mathrm{m}$, a minimal estimate of adhesion sites per cell was $30-40$. This estimate was considered minimal because of the apparently fragile nature of these structures (Bayer, 1979). Importantly, there was not a significant reduction $(P=$ $0.05)$ in the number of adhesion sites following the $42^{\circ} \mathrm{C}$ treatment of competent cells. Therefore, at least the vast majority of adhesion sites viewed in thin-section were not as heat labile as the less numerous 'patches' observed by freeze-etch techniques. This result seriously weakens any simple correlation between these two anatomical features.

Ferris \& Beveridge (1986) correlated the presence of 'patches' of this kind, observed in freeze- 

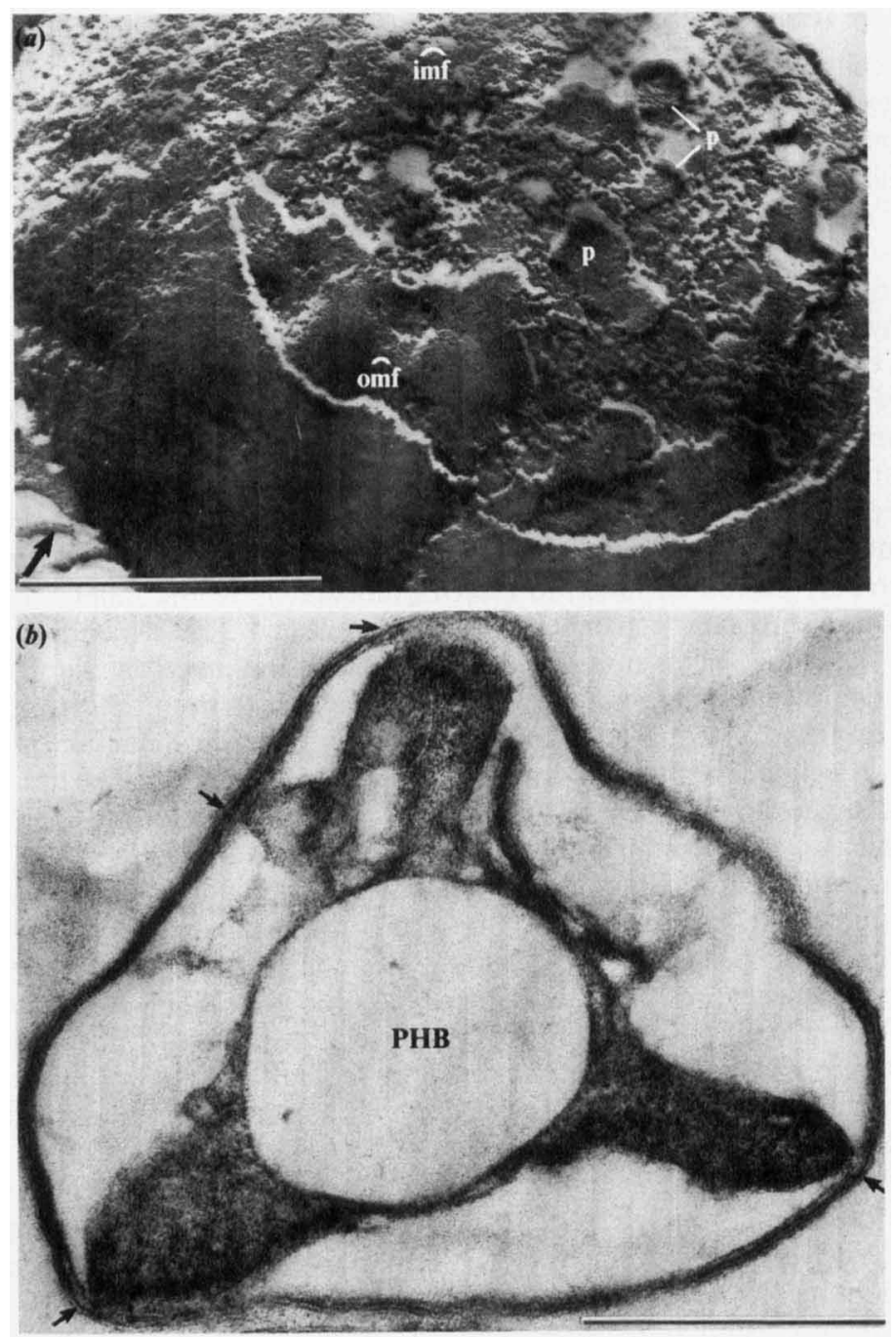

Fig. 4. (a) Freeze-etch replica of the convex surface of a cell from a competent population ( $\mathrm{Nif}^{+}$ transformation frequency $1.6 \times 10^{-2}$ ) of strain $\mathrm{UW} 1$. omf, outer membrane fracture face; imf, inner membrane fracture face; $p$, 'patches' - fragments of the inner leaflet of the outer membrane material present on the inner membrane fracture face. The arrow indicates the direction of platinum shadowing. Bar, $0.5 \mu \mathrm{m}$. (b) Electron micrograph of a thin section of a plasmolysed cell from a competent population of strain UW1. The specimen was stained with $5 \%(\mathrm{w} / \mathrm{v})$ uranyl acetate in methanol and $0.4 \%$ lead citrate in $0.1 \mathrm{M}-\mathrm{NaOH}$. Points of adhesion between the membranes are visible as regions where the inner and outer membranes remain closely apposed (arrows). A granule of poly- $\beta$-hydroxybutyrate (PHB) occupies the centre of the section. Bar, $0.5 \mu \mathrm{m}$.

etched preparations of $E$. coli, with $\mathrm{Ca}^{2+}$-deficiency of the cell envelope. To investigate this possibility in $A$. vinelandii, freeze-etch preparations of non-competent cells prepared by growth in calcium-limited Burk medium (Page \& Doran, 1981) were examined. Although these samples readily demonstrated the 'patches', so did cells from the same population following calciummediated competence recovery (data not shown), therefore no correlation between calcium deficiency and these ultrastructural features was established. Calcium deficiency is, however, known to disorganize the regular surface layer of $A$. vinelandii and result in a loss of transformation competence without substantial perturbation of the outer membrane (Doran et 
al., 1987; Page \& Doran, 1981). Examination of the phospholipid content of competent and noncompetent $A$. vinelandii strain UWl revealed no differences (Reusch \& Sadoff, 1983) and the fatty acid contents of the inner and outer membranes of competent and noncompetent strain UW I were not particularly dissimilar (Doran, 1983). Therefore, the type of dramatic alterations in the membrane lipid composition that might be expected if these ultrastructural features were the result of changes which might, somehow, cause a coalescence of membrane phospholipids (Ferris \& Beveridge, 1986) was not evident. Therefore, the nature of these 'patches' remains unknown.

Obviously, the treatment of cells at $42{ }^{\circ} \mathrm{C}$ is too crude a variable with which to establish a relationship between these ultrastructural observations and the physiological consequences of competence development or loss. Efforts to identify structural components of the DNA uptake system of competent $A$. vinelandii, including the identification of competence-specific membrane proteins (Doran, 1983; Page \& von Tigerstrom, 1982), surface-iodination of competent cells to identify DNA-binding proteins (W. H. Bingle \& W. J. Page, unpublished results) and pulse-chase experiments to identify specific membrane protein synthesis during competence recovery after $42^{\circ} \mathrm{C}$ treatment (Doran, 1983), have all failed to provide a competence-specific membrane protein 'marker' which could be used for further investigations to delineate the molecular architecture of the system responsible for DNA uptake.

\section{Conclusions}

The use of the naturally competent $A$. vinelandii OP does not provide a significant improvement over the use of artificially generated competent strain OP (David et al., 1981) for transformation by the broad-host-range plasmid pKT210. Given that strain OP is transformed at high frequency with a single chromosomal marker in a preparation of total chromosomal DNA (this study; Page, 1985) it was expected that plasmid transformation frequencies would approach $100 \%$, similar to the results reported for $A$. vinelandii 12837 (Glick et al., 1985). However, the frequency of pKT210 transformation was two to three orders of magnitude lower than that observed for an unpurified, homologous, chromosomal marker. The efficiency of transformation calculated for pKT210 transformation of strain UW10 was approximately $10^{4}$-fold lower than that reported for transformation of strain 12837 by RSF1010, the parental plasmid of pKT210 (Glick et al., 1985). The tendency of competent UW10 to begin to become saturated with pKT210 transforming DNA at levels greater than $100 \mathrm{ng}$ per $10^{7}$ cells also differs from the results obtained with $10^{7}$ cells of the encapsulated strain 12837 , which did not become saturated at levels of $51 \mu \mathrm{g}$ of transforming plasmid (pRK2501) DNA (Glick et al., 1985). Therefore, the dissimilarity in the plasmid transformation frequencies of strain OP and strain 12837 apparently represented a significant difference between these recipient strains. However, we have had difficulty generating chromosomal (Page, 1985) or plasmid transformants of the encapsulated strain 12837 or strain $\mathrm{O}$, the capsule ${ }^{+}$parental strain of strain OP (unpublished results), using the protocols which generate high levels of transformation competence in strain OP (Page, 1985). Therefore some significant difference(s) between the methods of competence development of Glick et al. (1985) and Page (1985) is assumed to exist.

The frequency of pKT210 transformation of strain OP was two orders of magnitude lower than the observed plasmid transformation frequency of naturally competent $H$. influenzae (Stuy \& Walter, 1986), B. subtilis (Contente \& Dubnau, 1979) or S. sanguis (Behnke, 1981), indicating that naturally competent $A$. vinelandii discriminated against heterologous plasmid DNA transformation more than these other bacteria. As was found with $H$. influenzae, competent $A$. vinelandii appeared to possess more than one mechanism for the discrimination against transformation by heterologous plasmid DNA.

This discrimination against transformation by pKT210 was found to be based partially on the fact that strain OP possesses a homology-facilitated transformation system. The phenomenon of homology-facilitated transformation has been well studied in several eubacterial natural transformation systems. The very low frequency of transformation of $H$. influenzae by linear plasmid DNA (one transformant per $10^{7}$ plasmid molecules; Stuy \& Walter, 1986) appears to be a result of the requirement that homologous DNA sequences be present in the recipient cell and 
the transforming plasmid (Stuy \& Walter, 1986). This is certainly a consequence of the fact that plasmid DNA is converted to a single-stranded form during uptake (Barany et al., 1983; Pifer \& Smith, 1985). A somewhat different phenomenon of homology-facilitated transformation has been documented in studies of the transformation of $B$. subtilis (Canosi et al., 1981) and $S$. pneumoniae (Lopez et al., 1982) by plasmid DNA containing homologous chromosomal DNA inserts. There is good evidence to support the hypothesis that in these transformation systems synapsis of the homologous region of the single-stranded plasmid DNA with the host chromosome was an obligate step in the survival of the transforming plasmid markers and the regeneration of circular duplex plasmid DNA (Canosi et al., 1981; Iglesias et al., 1981; Lopez et al., 1982). Notably, homology-facilitated transformation of $A$. vinelandii was clearly unlike that in S. pneumoniae (Lopez et al., 1982) or B. subtilis (Canosi et al., 1981; Iglesias et al., 1981) because recombination of the donor homologous marker with the host chromosomal DNA did not facilitate the regeneration of the plasmid replicon. Therefore, it will be important to develop recombination-deficient mutants of $A$. vinelandii $\mathrm{OP}$ for future use in molecular cloning and genetic analysis.

Linear plasmid DNA was threefold more active in transformation than the CCC or OC conformations of plasmid DNA. In the case of the heterologous plasmid pKT210 this enhancement was dependent upon the cohesive termini of linear DNA which had been generated by restriction enzyme digestion. However, in the case of a heterologous plasmid carrying a homologous DNA insert (pAvH1-1), flush-ended linear DNA was as active in transformation, suggesting that flush-ended linear DNA is transported into $A$. vinelandii $O P$, but that the survival of the donor markers is dependent upon a mechanism for ligation or recombination. The fate of plasmid DNA, including plasmids containing internal duplications of heterologous or homologous DNA, during the transformation of strain OP is currently under investigation.

This study has established that there are several common requirements for plasmid and chromosomal transformation, some of which relate to the mechanism of DNA binding and uptake. It has also emphasized the fact that it will be necessary to better understand the mechanism of genetic transformation in $A$. vinelandii and the fate of plasmid DNA during uptake before all of the characteristics of plasmid transformation can be explained. The ultrastructure of competent cells was examined as an initial approach to delineating the mechanism of DNA uptake. Similar reports describing specific ultrastructural features of naturally competent bacteria have not appeared in the literature, probably owing to the difficulty associated with correlating the results of physiological studies with those obtained by microscopy. We have shown that there are alterations in the cell envelope, detectable by freezeetch electron microscopy, which appear concurrent with the development of the ability of cells to take up transforming DNA. Although these results are very tentative, it is hoped that they may provide a new and useful avenue of research towards understanding the elusive physiology of the state of competence for genetic transformation of $A$. vinelandii $\mathrm{OP}$.

We thank Dr J. W. Costerton and Kan Lam, Biology Department, University of Calgary, for making the facilities for freeze-etch electron microscopy available to us. We are also indebted to Robert Carmichael for assistance with the preparation of ultrathin sections for electron microscopy and to Stuart Lee who assisted with the preparation of plasmid DNA. The plasmid pSa30 was a gift from Dr F. A. Ausubel, Harvard University, to W. J.P. and the plasmid pSa 747 was kindly provided to K. L. R. by Dr C. I. Kado, University of California, Davis. W.H. B. was supported by an Alberta Heritage Foundation for Medical Research (AHFMR) studentship and J.L.D. was supported by an AHFMR Postdoctoral Fellowship. This study was made possible by operating grants provided to K.L.R. and W. J.P. by the Natural Sciences and Engineering Research Council of Canada.

\section{REFERENCES}

Bagdasarian, M., Franklin, F. C. H., Lurz, R., RUCKert, B., Bagdasarian, M. M. \& Timmis, K. N. (1981). Specific purpose cloning vectors. II. Broad host range, high copy number RSF1010-derived vectors, and a host : vector system for gene cloning in Pseudomonas. Gene 16, 237-247.
Barany, F., KaHn, M. E. \& SMith, H. O. (1983). Directional transport and integration of donor DNA in Haemophilus influenzae transformation. Proceedings of the National Academy of Sciences of the United States of America 80, 7274-7278.

BAYER, M. E. (1979). The fusion sites between outer 
membrane and cytoplasmic membrane of bacteria: their role in membrane assembly and virus infection. In Bacterial Outer Membranes: Biogenesis and Functions, pp. 167-202. Edited by M. Inouye. New York: Wiley.

BAYER, M. E. \& LEIVE, L. (1977). Effect of ethylenediaminetetracetate upon the surface of Escherichia coli. Journal of Bacteriology 130, 1364-1381.

Bayer, M. E. \& Thurow, H. (1977). Polysaccharide capsule of Escherichia coli: microscope study of its size, structure and sites of synthesis. Journal of Bacteriology 130, $911-936$.

BEHNKE, D. (1981). Plasmid transformation of Streptococcus sanguis (Challis) occurs by circular and linear molecules. Molecular and General Genetics 182, 490497.

Bingle, W. H., Doran, J. L. \& Page, W. J. (1984). Regular surface layer of Azotohacter vinelandii. Journal of Bacteriology 159, 251-259.

BISHOP. P. E. \& BRILL, W. J. (1977). Genetic analysis of Azotobacter vinelandii mutant strains unable to fix nitrogen. Journal of Bacteriology 130, 954-956.

Bishop, P. E., Rizzo, T. M. \& BotT. K. F. (1985). Molecular cloning of nif DNA from Azotobacter vinelandii. Journal of Bacteriology 162, 21-28.

Bolivar, F. \& Backman, K. (1979). Plasmids of Escherichia coli as cloning vectors. Methods in Enzymology 68, 245-267.

Brigle, K. E., Newton, W. E. \& Dean, D. R. (1985). Complete nucleotide sequence of the Azotobacter vinelandii nitrogenase structural gene cluster. Gene 37, 37-44.

Cannon, F. C., Riedel, G. E. \& Ausubel, F. M. (1979). Overlapping sequences of Klebsiella pneumoniae nif DNA cloned and characterized. Molecular and General Genetics 174, 59-66.

Canosi, U., Iglesias, A. \& Trautner, T. A. (1981). Plasmid transformation in Bacillus subtilis: effects of insertion of Bacillus subtilis DNA into plasmid pC194. Molecular and General Genetics 181, 434440.

Cohen, S. N., Chang, A. C. Y. \& Hue, L. (1972). Nonchromosomal antibiotic resistance in bacteria: genetic transformation of Escherichia coli by R-factor DNA. Proceedings of the National Academy of Sciences of the United States of America 69. 2110 2114.

Collins, J. (1979). Escherichia coli plasmids packageable in vitro in $\lambda$ bacteriophage particles. Methods in Enzymology 68, 309-326.

Contente, S. \& Dubnau. D. (1979). Characterization of plasmid transformation in Bacillus subtilis: kinetic properties and the effect of DNA conformation. Molecular and General Genetics 167, 251-258.

Danner, D. B., Deich, R. A., Sisco, K. L. \& Smith, H. O. (1980). An eleven-base-pair sequence determines the specificity of DNA uptake in Haemophilus influenzae transformation. Gene 11, 311-318.

David, M., Tronchet, M. \& Denarie, J. (1981). Transformation of Azotobacter cinelandii with plasmids RP4 (IncP-1 group) and RSF1010 (IncQ group). Journal of Bacteriology 146, 1154-1157.

DEICH, R. A.\& HOYER, L. C. (1982). Germination and release of DNA-binding vesicles by Haemophilus influenzae during induction and loss of competence. Journal of Bacteriology 152, 855-864.
DORAN, J. L. (1983). Genetic transformation of Azotobacter vinelandii. PhD thesis, University of Alberta. National Library - Ottawa, 67258.

Doran, J. L. \& PaGe, W. J. (1983). Heat-sensitivity of Azotobacter vinelandii genetic transformation. Journal of Bacteriology 155, 159-168.

Doran, J. L., Bingle, W. H. \& Page, W. J. (1987). Role of calcium in the assembly of the Azotobacter vinelandii surface layer. Journal of General Microbiology 133, 399-413.

Ferris, F. G. \& Beveridge, T. J. (1986). Physiochemical roles of soluble metal cations in the outer membrane of Escherichia coli K-12. Canadian Journal of Microbiology 32, 594-601

Gergens, J. P., Stern. R. H. \& Wensink. P. C. (1979). Filter replicas and permanent collections of recombinant DNA plasmids. Nucleic Acids Research 7 , 2115-2136.

Glick, B. R., Brooks, H. E. \& Pasternak, J. J. (1985). Transformation of Azotobacter vinelandii with plasmid DNA. Journal of Bacteriology 162, 276-279.

Gromkova, R. \& GoOdGaL, S. (1981). Uptake of plasmid deoxyribonucleic acid by Haemophilus. Journal of Bacteriology 146, 79-84.

HaNaHAN. D. (1983). Studies on transformation of Escherichia coli with plasmids. Journal of Molecular Biology 166, 557-580.

Hanson, R. S. \& Phillips, J. A. (1981). Chemical composition. In Manual of Methods for General Bacteriology. pp. 328-364. Edited by P. Gerhardt, R. G. E. Murray, R. N. Costilow, E. W. Nester, W. A. Wood, N. R. Krieg \& G. B. Phillips. Washington, DC: American Society for Microbiology.

HoHN, B. (1979). In ritro packaging of $\lambda$ and cosmid DNA. Methods in Enzymology 68, 299-309.

Iglesias, A., Bensi, G., Canosi, U.\& Trautner, T. A. (1981). Plasmid transformation in Bacillus subtilis: alterations introduced into the recipient-homologous DNA of hybrid plasmids can be corrected in transformation. Molecular and General Genetics 184, 405-409.

Kahn. M. E., Maul, G. \& Goodgal, S. H. (1982). Possible mechanism for donor DNA binding and transport in Haemophilus. Proceedings of the National Academy of Sciences of the United States of America 79. $6370-6374$.

Kahn, M. E., Barany, F. \& SMith. H. O. (1983). Transformasomes: specialized membranous structures that protect DNA during Haemophilus transformation. Proceedings of the National Academy of Sciences of the United States of America 80, 69276931

KENNEDY, C. \& RoBson, R. L. (1983). Activation of nif gene expression in Azotobacter by the nif A gene product of Klebsiella pneumoniae. Nature, London 301. 626-628.

Lopez, P., Espinosa, M., Stassi, D. L. \& Lacks, S. A. (1982). Facilitation of plasmid transfer in Streptococcus pneumoniae by chromosomal homology. Journal of Bacteriology 150, 692-701.

LUNDELL, D. J. \& HowaRD, J. B. (1981). Isolation and sequences of the cysteinyl tryptic peptides from the MoFe-protein of Azotobacter vinelandii nitrogenase. Journal of Biological Chemistry 256, 6385-6391.

Maniatis, T., Fritsch, E. F. \& SAMbrook, J. (1982). Molecular Cloning: a Laboratory Manual. Cold 
Spring Harbor, New York: Cold Spring Harbor Laboratory.

MORRISON, D. A. (1979). Transformation and preservation of competent bacterial cells by freezing. Methods in Enzymology 68, 326-331.

PAGE, W. J. (1982). Optimal conditions for induction of competence in nitrogen-fixing Azotobacter vinelandii. Canadian Journal of Microbiology 28, 389-397.

PAGE, W. J. (1985). Genetic transformation of molybdenum-starved Azotobacter vinelandii: increased transformation frequency and recipient range. Canadian Journal of Microbiology 31, 659-662.

PAGE, W. J. \& DORAN, J. L. (1981). Recovery of competence in calcium-limited Azotobacter vinelandii. Journal of Bacteriology 146, 33-40.

PAGE, W. J. \& SadofF, H. L. (1976). Physiological factors affecting transformation of Azotobacter vinelandii. Journal of Bacteriology 125, 1080-1087.

PAGE, W. J. \& VON Tigerstrom, M. (1978). Induction of transformation competence in Azotobacter vinelandii iron-limited cultures. Canadian Journal of Microbiology 24, 1590-1594.

Page, W. J. \& von Tigerstrom, M. (1979). Optimal conditions for transformation of Azotobacter vinelandii. Journal of Bacteriology 139, 1058-1061.

PAge, W. J. \& von Tigerstrom, M. (1982). Iron- and molybdenum-repressible outer membrane proteins in competent Azotobacter vinelandii. Journal of Bacteriology 151, 237-242.

PEACHY, L. D. (1958). Thin sections, I. A study of section thickness and physical distortion produced during microtomy. Journal of Biophysical and Biochemical Cytology 4, 233-242.

PIFER, M. L. \& SMITH, H. O. (1985). Processing of donor DNA during Haemophilus influenzae transformation: analysis using a model plasmid system. Proceedings of the National Academy of Sciences of the United States of America 82, 3731-3735.
ReusCh, R. N. \& SADOFF, H. L. (1983). D-(-)-Poly- $\beta$ hydroxybutyrate in membranes of genetically competent bacteria. Journal of Bacteriology 156, 778-788.

Robinson, A. C., Burgess, B. K. \& Dean, D. R. (1986). Activity, reconstitution and accumulation of nitrogenase components in Azotobacter vinelandii mutant strains containing defined deletions within the nitrogenase structural gene cluster. Journal of Bacteriology 166, 180-186.

Sanger, F., Nicklen, S. \& Coulson, A. R. (1977). DNA sequencing with chain terminating inhibitors. Proceedings of the National Academy of Sciences of the United States of America 74, 5463-5467.

SAUNDERS, C. W. \& GuILD, W. R. (1981). Pathway of plasmid transformation in pneumococcus: open circular and linear molecules are active. Journal of Bacteriology 146, 517-526.

SOUTHERN, E. (1979). Gel electrophoresis of restriction fragments. Methods in Enzymology 68, 152-176.

StUY, J. H. \& Walter, R. B. (1986). Homologyfacilitated plasmid transfer in Haemophilus influenzae. Molecular and General Genetics 203, 288-295.

Tait, R. C., Close, T. J., Lundquist, R. C., Hagiya, M., Rodriguez, R. L. \& Kado, C. I. (1983). Construction and characterization of a versatile broad host range DNA cloning system for gramnegative bacteria. Bio/Technology 1, 269-275.

Thompson, J. P. \& SkeRman, V. B. D. (1979). Azotobacteriaceae: the Taxonomy and Ecology of the Aerobic Nitrogen-fixing Bacteria, pp. 126-127, 202203. London: Academic Press.

Vieira, J. \& Messing, J. (1982). The pUC plasmids, and M13mp7-derived system for the insertion mutagenesis and sequencing with synthetic universal primers. Gene 19, 259-268.

de Vos, W. M., Venema, G., Canosi, U. \& Trautner, T. A. (1981). Plasmid transformation in Bacillus subtilis: fate of plasmid DNA. Molecular and General Genetics 181, 424-433. 